\title{
Complement component 3 (C3) expression in the hippocampus after excitotoxic injury: role of $\mathrm{C} / \mathrm{EBP} \beta$
}

\author{
Elena Hernandez-Encinas ${ }^{1,2+}$, Diana Aguilar-Morante ${ }^{1,5 \dagger}$, Jose A. Morales-Garcia ${ }^{1,2}$, Elena Gine ${ }^{4}$, \\ Marina Sanz-SanCristobal ${ }^{1,2}$, Angel Santos ${ }^{2,3^{*}}$ and Ana Perez-Castillo ${ }^{1,2^{*}}$ (D)
}

\begin{abstract}
Background: The CCAAT/enhancer-binding protein $\beta$ (C/EBP $\beta)$ is a transcription factor implicated in the control of proliferation, differentiation, and inflammatory processes mainly in adipose tissue and liver; although more recent results have revealed an important role for this transcription factor in the brain. Previous studies from our laboratory indicated that CCAAT/enhancer-binding protein $\beta$ is implicated in inflammatory process and brain injury, since mice lacking this gene were less susceptible to kainic acid-induced injury. More recently, we have shown that the complement component 3 gene (C3) is a downstream target of CCAAT/enhancer-binding protein $\beta$ and it could be a mediator of the proinflammatory effects of this transcription factor in neural cells.
\end{abstract}

Methods: Adult male Wistar rats (8-12 weeks old) were used throughout the study. C/EBP $\beta^{+/+}$and C/EBP $\beta^{-/-}$mice were generated from heterozygous breeding pairs. Animals were injected or not with kainic acid, brains removed, and brain slices containing the hippocampus analyzed for the expression of both CCAAT/enhancer-binding protein $\beta$ and C3.

Results: In the present work, we have further extended these studies and show that CCAAT/enhancer-binding protein $\beta$ and C3 co-express in the CA1 and CA3 regions of the hippocampus after an excitotoxic injury. Studies using CCAAT/enhancer-binding protein $\beta$ knockout mice demonstrate a marked reduction in C3 expression after kainic acid injection in these animals, suggesting that indeed this protein is regulated by C/EBP $\beta$ in the hippocampus in vivo.

Conclusions: Altogether these results suggest that CCAAT/enhancer-binding protein $\beta$ could regulate brain disorders, in which excitotoxic and inflammatory processes are involved, at least in part through the direct regulation of $\mathrm{C} 3$.

Keywords: C/EBP $\beta, C 3$, Excitotoxicity, Neurodegeneration, Neuroinflammation

\section{Background}

CCAAT/enhancer-binding protein $\beta(C / E B P \beta)$ is a member of a family of transcription factors whose members contain a basic leucine-zipper domain for DNA binding and dimerization $[1,2] . C / E B P \beta$ exists in three isoforms generated from a single messenger

\footnotetext{
* Correspondence: piedras3@med.ucm.es; aperez@iib.uam.es

${ }^{\dagger}$ Equal contributors

${ }^{2}$ Centro de Investigación Biomédica en Red sobre Enfermedades

Neurodegenerativas (CIBERNED), 28031 Madrid, Spain

'Instituto de Investigaciones Biomédicas, (CSIC-UAM), Arturo Duperier, 4,

28029 Madrid, Spain

Full list of author information is available at the end of the article
}

RNA (mRNA) due to alternative translation initiation sites $[3,4]$. C/EBP $\beta$ is expressed in numerous tissues, including liver, adipose tissue, kidney, lung, ovary, mammary gland, and hematopoietic tissues, and regulates a variety of biological processes, including metabolism, proliferation and differentiation (depending on the cell context), and immune response $[1,5-8]$.

In the nervous system, $C / E B P \beta$ is essential for regulating numerous processes such as synaptic plasticity and longterm memory $[9,10]$, neuronal differentiation $[11,12]$, neuroinflammation and excitotoxicity [13-16], and hippocampal neurogenesis [17]. Also, due to its relevance in the 
indicated cellular processes, C/EBP $\beta$ is also involved in the pathogenesis of different diseases, e.g., cancer, hyper-inflammatory processes, and bacterial infections $[1,18,19]$. As it happens in normal physiological conditions, this regulation takes place via the regulation of many genes involved in these processes [15-17, 20, 21].

The complement pathway is an essential regulator of the immune response, including chemotaxis, phagocytosis, cell adhesion, and $\mathrm{B}$ and $\mathrm{T}$ cell differentiation $[22,23]$, and it is a very important line of defense against infections through the elimination of invading pathogens and regulation of the adaptive immune response [24, 25]. Regarding the central nervous system, several studies have shown that the complement system plays also important roles in the central nervous system that extend far beyond host defense and inflammatory processes [26-32]. Specifically, complement component 3 (C3), a central component of the complement cascade, is a critical mediator of synaptic refinement and plasticity [31, 33] and localizes at synapsis where it mediates its pruning during development [31, 34], normal aging [35], and neurodegeneration [36, 37]. In fact, mice deficient in C3 exhibit deficits in synaptic remodeling, increased synaptic connectivity, and enhanced epileptiform activity due to failed synaptic pruning [38]. It has been also shown that $\mathrm{C} 3$ regulates hippocampal neurogenesis in adult mammalian brain [39] and C3-deficient mice present impaired neurogenesis following cerebral ischemia $[40,41]$.

Besides its role in normal physiological conditions, also uncontrolled complement activation in the brain has been associated with various neurodegenerative disorders, including Alzheimer's disease, Parkinson's disease, Huntington' disease, dementia, and multiple sclerosis [30, 42-50]. Increased levels of C3 have been found in the cerebrospinal fluid (CSF) of patients with Parkinson's and Alzheimer's diseases, and these levels augment with the progression of the disease [49]. Zanjani et al. showed that C3 localized surrounding $\beta$ amyloid plaques in early stages of Alzheimer's disease, when an important loss of synapsis takes place [51], and other authors have demonstrated a modulatory role of C3 on amyloid pathology in animal models of Alzheimer's disease $[52,53]$. However, little is known about the mechanisms regulating C3 expression and its influence on neuronal function and dysfunction in the adult brain.

Taking into account the previous results from our laboratory showing a direct regulation of $\mathrm{C} 3$ by $\mathrm{C} / \mathrm{EBP} \beta$ in neural cells [54], here we examined the possible regulation by $\mathrm{C} / \mathrm{EBP} \beta$ of $\mathrm{C} 3$ expression in the hippocampus in an animal model of excitotoxicity. For this purpose, we have analyzed the expression of both $C / E B P \beta$ and $C 3$ after an excitotoxic injury induced by kainic acid (KA) injection in the hippocampus of rodents (rats and mice). Our results reveal a strong induction of $C / E B P \beta$ and $C 3$ in the CA1 and CA3 regions of the hippocampus following kainic acid injection. We also show a pronounced reduction of $C 3$ levels in $C / E B P \beta$ knockout mice, which have reduced neurotoxicity [16]. These data point to a role for $\mathrm{C} 3$ as a possible mediator of the effects of $\mathrm{C} /$ $\mathrm{EBP} \beta$ in inflammatory and excitotoxic processes in vivo.

\section{Methods \\ Animals}

Adult male Wistar rats (8-12 weeks old) were used throughout the study. $\mathrm{C} / \mathrm{EBP} \beta^{+/+}$and $\mathrm{C} / \mathrm{EBP} \beta^{-/-}$mice were generated from heterozygous breeding pairs, kindly provided by C. M. Croniger and R. W. Hanson (Case Western Reserve University, Cleveland, $\mathrm{OH}$ ) [55]. Genotypes were identified using genomic PCR, with DNA prepared from tail using the REDExtract-N-AmpTM tissue PCR kit (XNAT kit, Sigma, St Louis, MO). Five animals from each experimental group were analyzed. All procedures with animals were specifically approved by the "Ethics Committee for Animal Experimentation" of the Instituto de Investigaciones Biomédicas and carried out in accordance with the European Communities Council, directive 2010/63/EEC and National regulations, normative $53 / 2013$. Special care was taken to minimize pain or discomfort of animals.

\section{Kainic acid injection in vivo}

Adult male rats, $\mathrm{C} / \mathrm{EBP} \beta^{+/+}$and $\mathrm{C} / \mathrm{EBP} \beta^{-/-}$mice, were anesthetized by intraperitoneal injection of ketamine $(60 \mathrm{mg} / \mathrm{kg})$ and medetomidine $(0.125 \mathrm{mg} / \mathrm{kg})$ and positioned in a stereotaxic apparatus (Kopf Instruments, CA). Kainic acid (KA) $(0.25 \mu \mathrm{g}$ in $2.50 \mu \mathrm{l}$ PBS $)$ was delivered unilaterally into the left hippocampus. Flow rate $(1 \mu \mathrm{l} / \mathrm{min})$ was kept constant with a motorized syringe pump (BASi), and the needle was kept in place for 2 min post-injection before being slowly withdrawn. Control animals of the same age were injected with vehicle. Animals were then housed individually to recover and sacrificed $72 \mathrm{~h}$ after lesioning with KA.

\section{Quantitative real-time-PCR}

Total rat or mouse hippocampal RNA samples $(2 \mu \mathrm{g})$ were used for the synthesis of complementary DNA (cDNA) by reverse transcription using the Reverse Transcription System (Promega, Madison, WI, USA) with a $\operatorname{pd}(\mathrm{N}) 6$ random hexamer. Real-time PCR was performed in an ABI Prism machine using the SYBR Green PCR Master Mix (Applied Biosystems, Warrington, UK) and $300 \mathrm{nM}$ concentrations of specific primer. The primers used for the determination of the concentration of both rat and mouse C3 mRNA were $5^{\prime}$-ACC TTA CCT CGG CAA GTT TCT-3' (forward sequence) and 5'-TTG TAG AGC TGC TGG TCA GG-3'(reverse sequence), which synthesized a fragment of $140 \mathrm{bp}$. In all 
runs, melting curves were performed to ensure that only one DNA fragment was amplified. Cycle threshold (dilution 1:10) was around 25. Amplification of the $18 \mathrm{~S}$ rRNA was used for normalization of cDNA loading in the PCR as previously described [56]. The relative mRNA content was determined with the $2-\Delta \Delta C t$ method [57].

\section{Immunohistochemistry}

Animals previously anesthetized were perfused transcardially with $4 \%$ paraformaldehyde, and the brains were removed, postfixed, and processed for immunohistochemistry using the diaminobenzidine (DAB) method or double-immunofluorescence analysis, as previously described [58]. The following primary antibodies were used: rabbit polyclonal anti-C3 (Abcam, Cambridge, UK), mouse monoclonal anti-C/EBP $\beta$ (Abcam, Cambridge, UK), rabbit polyclonal anti-NeuN (Merck-Millipore, Darmstadt, Alemania), rabbit polyclonal anti-IL-1 $\beta$ (Abcam), rat monoclonal anti-CD11b (clon OX42, Serotec, Oxford, UK), and rabbit polyclonal anti-glial fibrillary acidic protein (GFAP, Dako, Glostrup, Denmark) for immunodetection of astrocytes. For immunofluorescence analysis to detect C3, a secondary Alexa-Fluor488 goat anti-rabbit was used in combination with Texas Red Lycopersicon esculentum (tomato lectin; Vector Labs USA, emission at 546) to label microglial cells or Neurotrace fluorescent Nissl stain (emission at 546; Molecular Probes, Madrid, Spain) to stain neurons. The slides processed with DAB were examined with a Nikon Eclipse 80i (Düsseldorf, Germany) microscope, equipped with a Nikon DS-Fi1 digital camera. For double immunofluorescence, a LSM710 laser scanning spectral confocal microscope (Zeiss) was used. Confocal microscope settings were adjusted to produce the optimum signal-to-noise ratio. Orthogonal image acquisition was performed as previously described [59]. Briefly, sections containing the CA3 region of the hippocampus were used for the analysis. Confocal acquisitions with orthogonal projections show co-localization of $\mathrm{C} 3 /$ neurotrace, C3/GFAP, and C3/tomato lectin, over the extent of the cell in consecutive 0.5 - or 2 - $\mu \mathrm{m}$ z-stacks.

A differential interference contrast (DIC) microscope was used to identify the morphology of cells. The images were acquired using a Nikon 90i microscope equipped with a Plan Apo 100× Ph3 DM objective and connected to Nis-Elements BR software.

\section{Fluoro-Jade staining}

To evaluate neuronal degeneration, Fluoro-Jade B staining was used [60]. Briefly, sections mounted in gelatin-coated slides were immersed in $100 \%$ alcohol, followed by $70 \%$ alcohol and distilled water containing permanganate. Slides were then incubated with
0.001 Fluoro-Jade B dye (Chemicon, Temecula, USA) for $30 \mathrm{~min}$ at room temperature. After staining, sections were washed with distilled water and mounted with DePeX (Serva).

\section{TUNEL staining}

Frozen hippocampal sections were mounted in gelatincoated slides. The TUNEL protocol was performed using the In Situ Cell Death Detection Kit, POD (Roche Diagnostics, Indianapolis, USA), following the manufacturer's instructions. Slides were mounted with Vectashield (Vector Laboratories), and TUNEL staining was visualized and imaged using a Nikon Eclipse 80i (Düsseldorf, Germany) microscope, equipped with a Nikon DS-Fi1 digital camera.

\section{Results}

Kainic acid induced neurodegeneration in the CA3 region of the hippocampus in rats and mice

First, we validated our models of excitotoxicity by analyzing the damaging effect of KA in the CA3 subfield, which is the most sensitive area of the hippocampus to this excitotoxin. As expected, we found a dramatic increase in the number of degenerating neurons stained with Fluoro-Jade $\mathrm{B}$ (Fig. 1a) in rats and mice injected with $\mathrm{KA}$, which was more noticeable in the pyramidal cells of this area. We also found that this cell death occurs via apoptosis since a significant increase in the number of $\mathrm{TUNEL}^{+}$cells (Fig. 1b) was also observed, which was not detected in $\mathrm{C} /$ EBP $\beta$-deficient mice (Fig. 1b).

\section{$\mathrm{KA}$ induces the expression of C/EBP $\beta$ and $\mathrm{C} 3$ genes in the hippocampus of adult rats}

We next studied the content of $\mathrm{C} / \mathrm{EBP} \beta$ and $\mathrm{C} 3$ proteins, by immunohistochemistry analysis, in consecutive slices of the hippocampus of adult rats after KA injury. As shown in Fig. 2a, C/EBP $\beta$ and $\mathrm{C} 3$ proteins are barely detectable in the hippocampus of control animals. In contrast, after KA injection, a dramatic increase of both proteins was observed, which was most prominent in the CA3 subfield of the hippocampus (Fig. 2a). No expression of either $\mathrm{C} / \mathrm{EBP} \beta$ or $\mathrm{C} 3$ was detected in other hippocampal areas. It is known that the injection of KA can cause the rupture of the blood brain barrier (BBB) allowing the entry of plasmatic proteins into the brain. Therefore, we next analyzed whether the C3 protein found in the CA3 region after KA injection comes from outside the central nervous system or is due to a local synthesis in the hippocampus. To this end, we studied the hippocampal amount of C3 mRNA by quantitative PCR. Figure $2 b$ shows that in fact $\mathrm{C} 3 \mathrm{mRNA}$ was also increased after $\mathrm{KA}$ injection indicating that the observed increase in C3 protein is caused, at least in part, by an increase in the production of C3 gene in brain cells. 


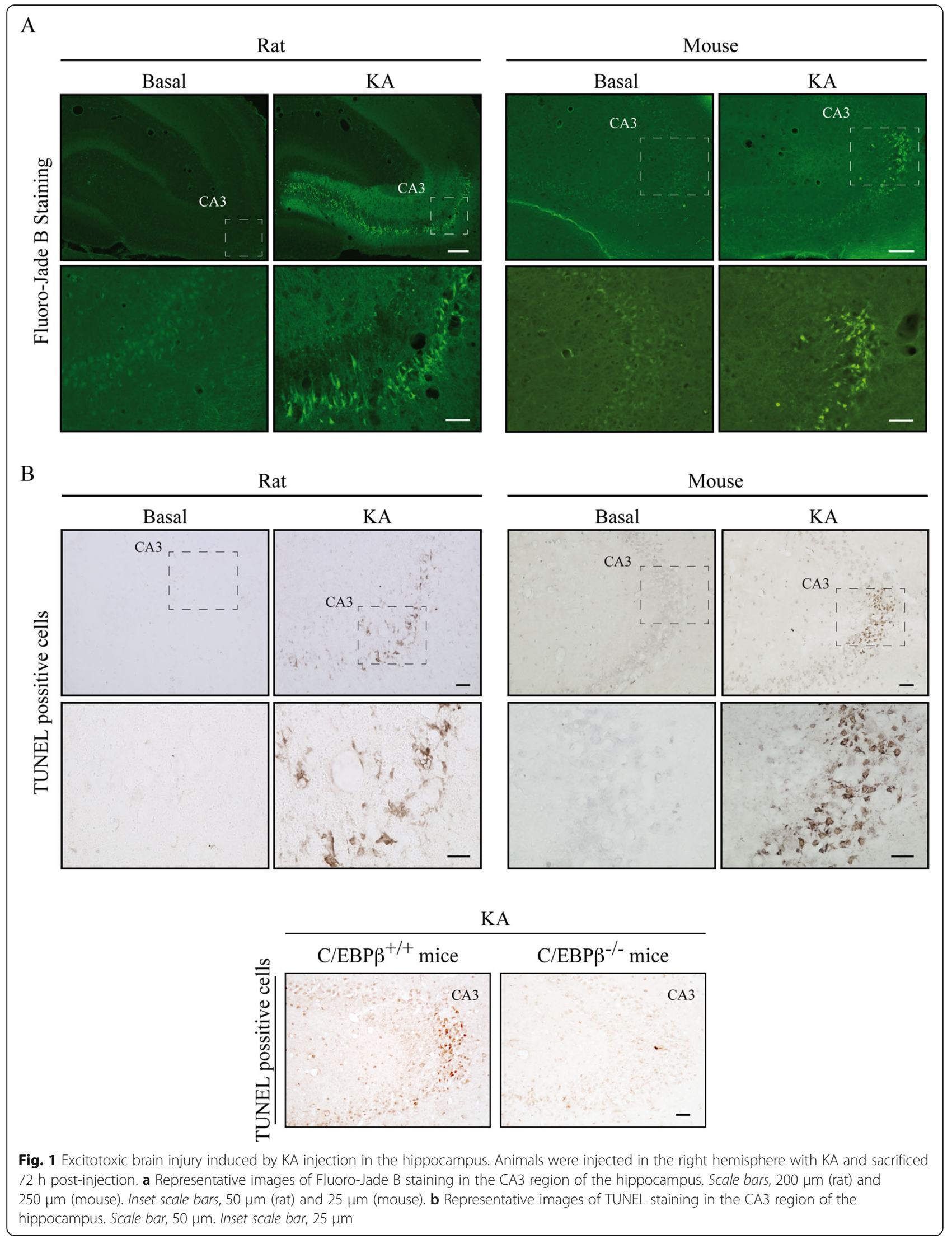




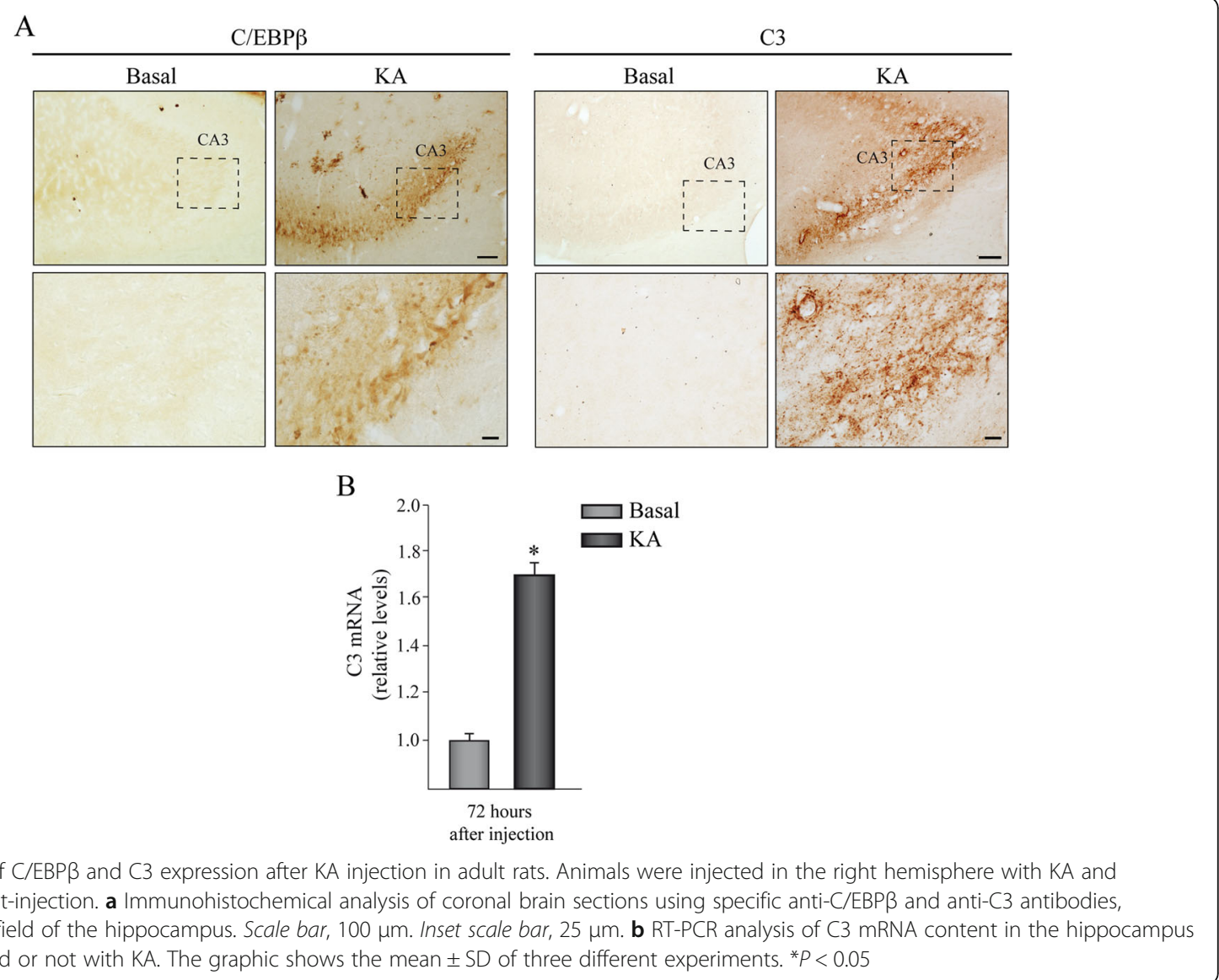

\section{$\mathrm{KA}$ induces C3 expression in neurons and glial cells in the hippocampus of adult rats}

Next we analyzed the cell types responsible for the KAinduced increase in $\mathrm{C} 3$ observed in the rat hippocampus. For that purpose, we performed double immunostaining in the $\mathrm{CA} 3$ region of the rat hippocampus, the region were the induction of $\mathrm{C} 3$ is most prominent. As shown in Fig. 3a, double labeling with a C3-specific antibody and neurotrace, a specific marker for neurons, clearly indicates the presence of $\mathrm{C} 3$ protein inside the neurons and also in the surrounding area $72 \mathrm{~h}$ after KA injection. Given the massive neuronal cell death that takes place in this region of the hippocampus, these observations suggest that C3 may be localized in those neurons that are already degenerating.

After brain injury, there is an increase in the number of reactive glial cells, both active astrocytes and microglial cells as labeled with a GFAP-specific antibody and tomato lectin, respectively. As expected, after KA injection, we observed an increase of both types of reactive glial cells. The presence of $\mathrm{C} 3$ protein was detected in both microglial cells and astrocytes, as shown in Fig. 3b, c, respectively. In addition, double-immunofluorescence analysis shows that the increase in $C / E B P \beta$ levels observed in wild type animals takes place in neurons (Fig. 3d).

Interestingly an increase in C3 labeling was clearly observed surrounding the microvasculature of the KAinjected hippocampus (Additional file 1) suggesting an implication of this protein in angiogenesis. Additionally, in this Figure, after double staining with a C3-specific antibody and tomato lectin, we show images of C3 localization near microglial cells suggesting also the opsonization and phagocytosis functions of C3 and microglial cells.

\section{$\mathrm{KA}$ induces the expression of C/EBP $\beta$ and $\mathrm{C} 3$ genes in the hippocampus of adult mice}

Next, we analyzed whether the coexpression of C3 and $\mathrm{C} / \mathrm{EBP} \beta$ in the same areas of the hippocampus also took place in mice. We find also a dramatic increase in the amount of $\mathrm{C} / \mathrm{EBP} \beta$ and $\mathrm{C} 3$ proteins in the hippocampus after KA injection. As shown in Fig. 4a, both proteins are almost undetectable in controls in the diverse regions of the hippocampus analyzed. A clear increase is observed after KA injection; however, and in contrast with rats, we could detect $\mathrm{C} / \mathrm{EBP} \beta$ and $\mathrm{C} 3$ proteins in three different regions of the hippocampus, CA1, CA3, and dentate gyrus (DG). Figure $4 b$ shows differential 

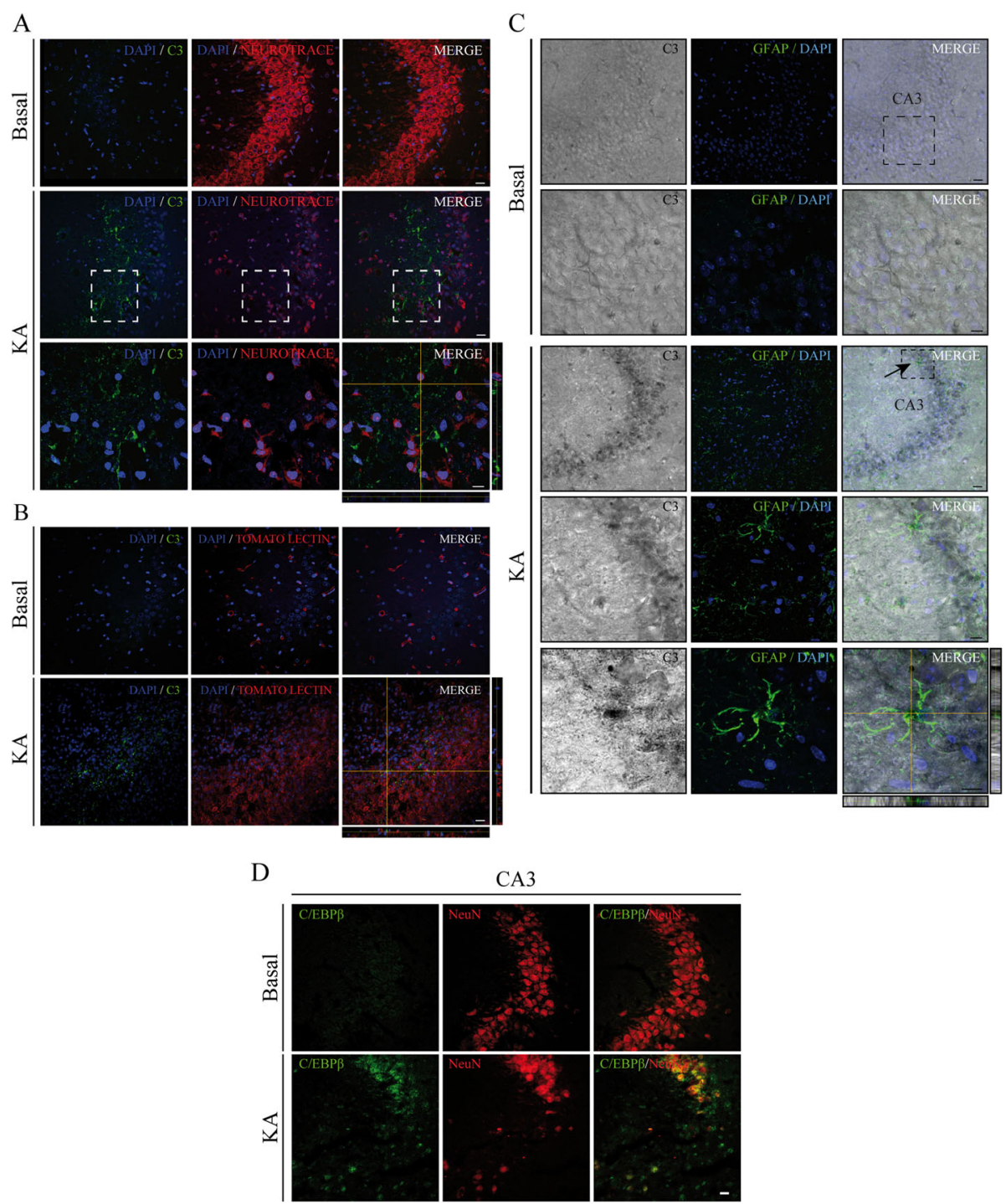

Fig. 3 Induction of C3 expression after KA injection in neurons and glial cells in the CA3 region of the hippocampus of adult rats. a Double fluorescent immunohistochemistry showing C3 expression (green) near hippocampal neurons labeled with neurotrace (red). b Representative images showing the expression of C3 (green) and microglial cells stained with tomato lectin (red). c Immunohistochemistry performed using a fluorescent antibody against GFAP (green) together with a DAB-stained anti-C3. Scale bar, $20 \mu \mathrm{m}$. Inset scale bar, $10 \mu \mathrm{m}$. DAPI was used as a nuclear marker. All images represent the maximum intensity projection, and orthogonal views are also shown, generated by projecting $z$-series in the $x$ - and $y$-planes. $\mathbf{d}$ Double-immunofluorescence images showing C/EBP $\beta$ expression after KA injection in neuronal cells (NeuN-positive cells). Scale bar, $50 \mu \mathrm{m}$

interference contrast (DIC) images of $\mathrm{C} / \mathrm{EBP} \beta$ and $\mathrm{C} 3$ to show the whole cell. A combination of DAB (C3) and fluorescence $(\mathrm{C} / \mathrm{EBP} \beta)$ staining shows that the increase of both proteins occurs in the same cells (Fig. 4c).

The absence of C/EBP $\beta$ blocks the induction of $\mathrm{C} 3$ by KA in the mouse hippocampus

In order to determine the causative implication of $\mathrm{C} /$ $\mathrm{EBP} \beta$ in the KA-induced expression of the $\mathrm{C} 3$ gene, we analyzed the effect of KA injection in the hippocampal expression of $\mathrm{C} 3$ gene in $\mathrm{C} / \mathrm{EBP} \beta^{-/-}$mice. As can be observed in Fig. 5a, C3 protein levels were clearly increased relative to vehicle-injected controls in the hippocampus $72 \mathrm{~h}$ following KA injection of $\mathrm{C} / \mathrm{EBP} \beta^{+/+}$ animals. On the contrary, no increase in $\mathrm{C} 3$ was observed in the hippocampus of $\mathrm{C} / \mathrm{EBP} \beta^{-/-}$mice. These data further support the notion that the transcription factor $C / E B P \beta$ is a major regulator of $C 3$ gene expression in the brain [54]. Furthermore, our results show that mice lacking $C / E B P \beta$ do not present an increase in C3 mRNA levels after the lesion (Fig. 5b), further indicating that indeed $\mathrm{C} / \mathrm{EBP} \beta$ is essential to induce $\mathrm{C} 3$ 


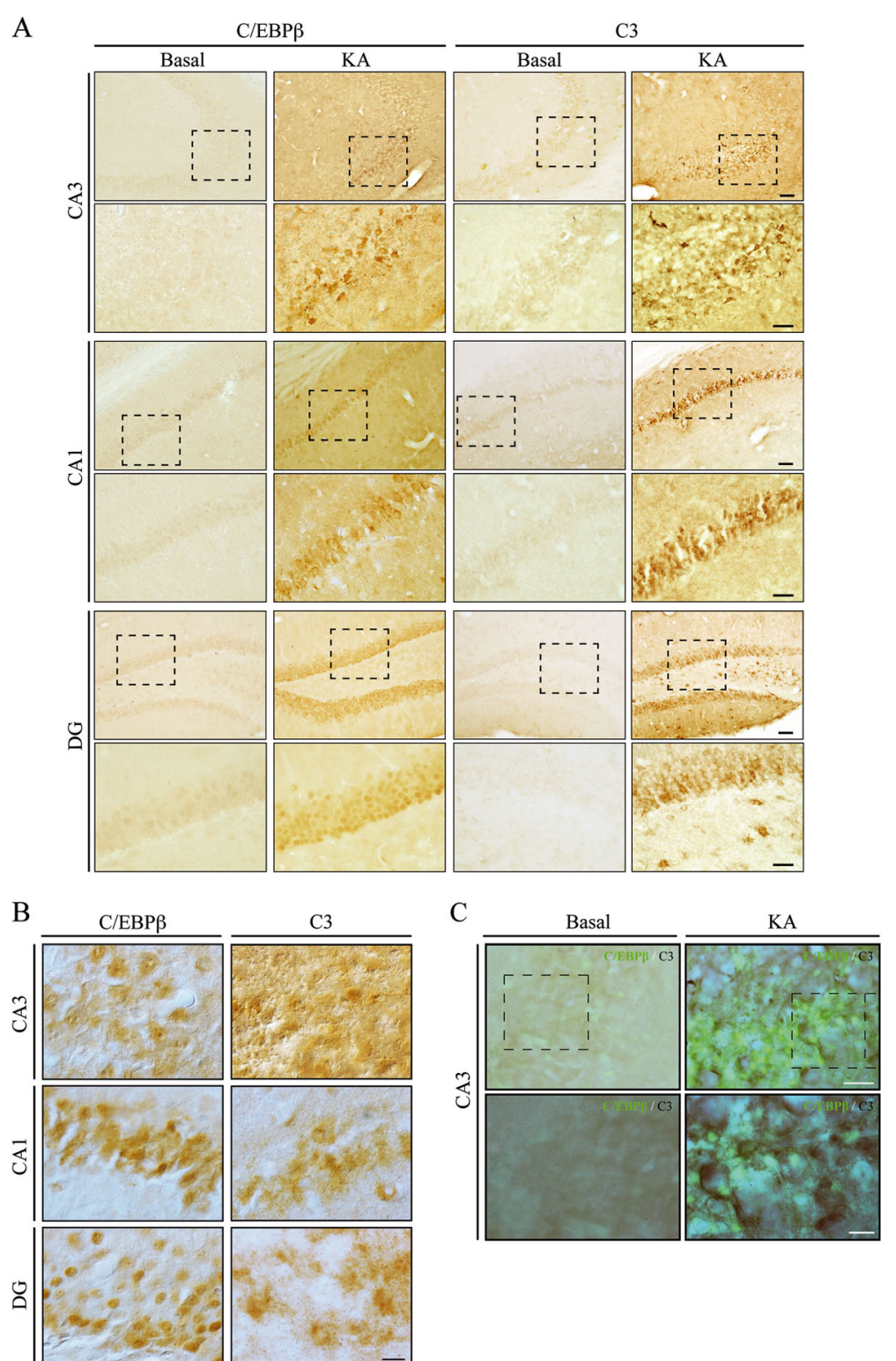

Fig. 4 Induction of C/EBP $\beta$ and C3 expression after KA injection in adult mice. Animals were injected in the right hemisphere with KA and sacrificed $72 \mathrm{~h}$ post-injection. a Immunohistochemical analysis of coronal brain sections using specific anti-C/EBP $\beta$ and anti-C3 antibodies, showing the CA3, CA1, and DG fields of the hippocampus. Scale bar, $50 \mu \mathrm{m}$. Inset scale bar, $25 \mu \mathrm{m}$. b Differential interference contrast images of coronal brain sections using specific anti-C/EBP $\beta$ and anti-C3 antibodies, showing the CA3, CA1, and DG fields of the hippocampus. Scale bar, $10 \mu m$. c Representative images showing coexpression of C3 (DAB staining) and C/EBPß (fluorescence) in the CA3 region. Scale bar, $20 \mu \mathrm{m}$. Inset scale bar, $10 \mu \mathrm{m}$

expression in the hippocampus and also suggesting a local production of $\mathrm{C} 3$.

One of the events that takes place in the hippocampus after KA injury is the activation of microglial cells and the liberation of proinflammatory cytokines, which is in part responsible for the neuronal degeneration. Glial activation (as shown by GFAP- and OX42-positive cells) and induction of IL1 $\beta$ (a very potent proinflammatory agent) were clearly observed in the hippocampus of wild type mice $72 \mathrm{~h}$ after KA injection (Fig. 6). This strong neuroinflammation process was completely absent in the hippocampus of $\mathrm{C} / \mathrm{EBP} \beta^{-/-}$mice.

\section{Discussion}

In this work, we focused on the analysis of coexpression of $C / E B P \beta$ and $C 3$ in an in vivo model of excitotoxicity. We chose this model since previous studies from our laboratory demonstrate an important role of $C / E B P \beta$ in excitotoxic processes [16]. Our results show that the injection of KA induces the expression of $\mathrm{C} / \mathrm{EBP} \beta$ and 


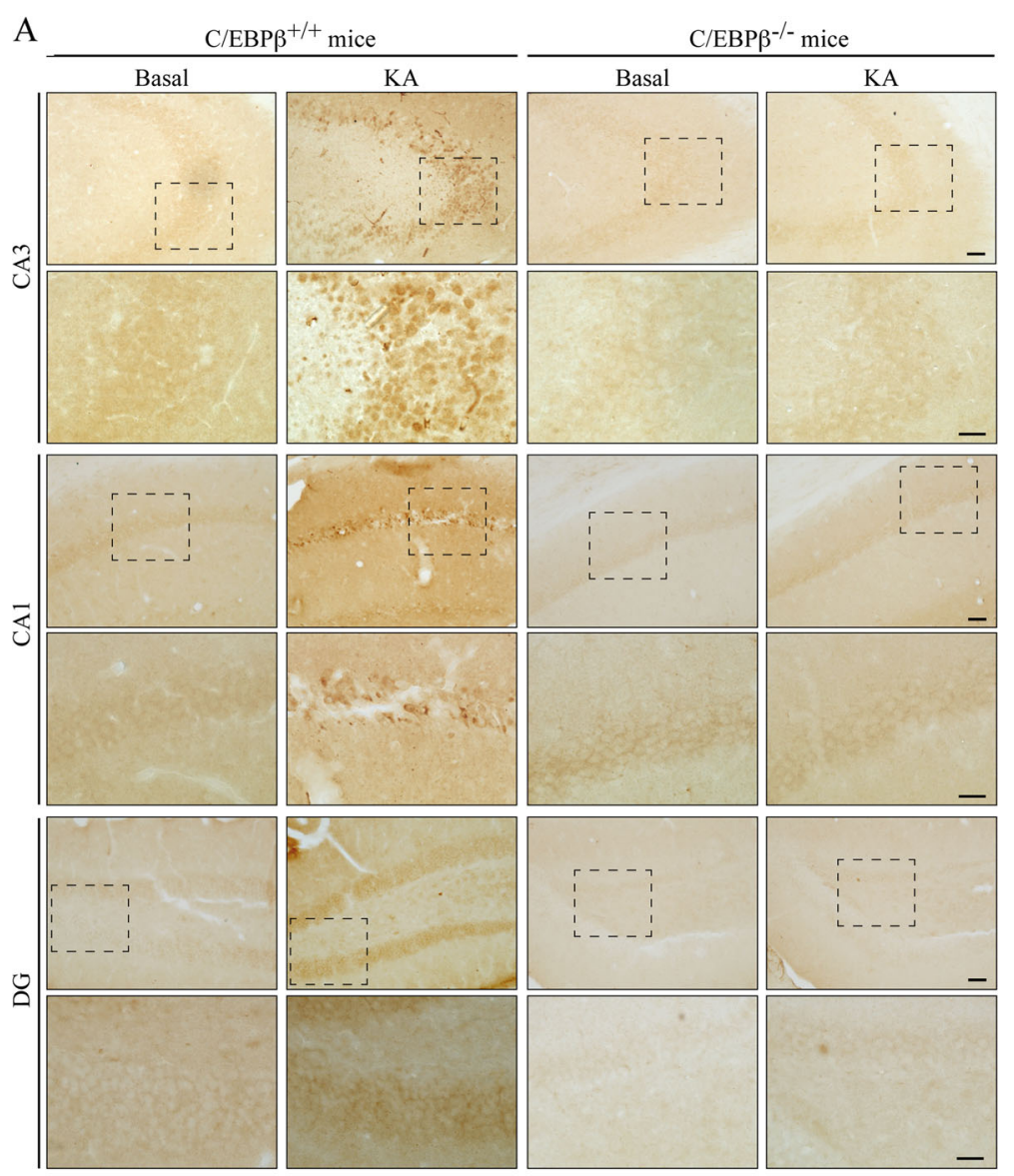

$\mathrm{B}$

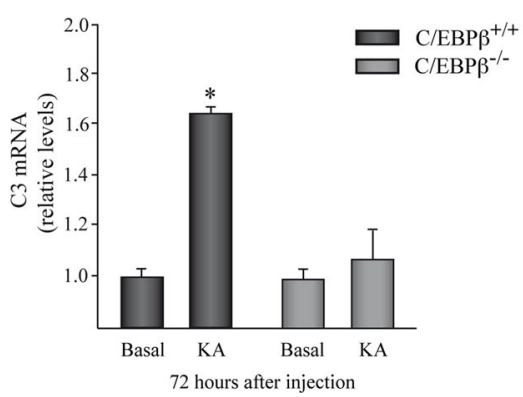

Fig. 5 Expression of C3 in C/EBP $\beta$ wild type and knockout mice. Mice were injected with KA in the right hemisphere, sacrificed $72 \mathrm{~h}$ later. a Immunohistochemistry analysis of coronal brain sections using an specific anti-C3 antibody showing the CA3, CA1, and DG fields of the hippocampus. No induction in the expression of C3 was observed in C/EBP $\beta$ knockout mice after KA injection, compared with their wild type littermate controls. Scale bar, $50 \mu \mathrm{m}$. Inset scale bar, $25 \mu \mathrm{m}$. b RT-PCR analysis of C3 mRNA content in the hippocampus of adult C/EBP $\beta^{+/+}$and $\mathrm{C} / \mathrm{EBP}^{-1-}$ mice treated or not with KA. The graphic shows the mean of three different experiments

C3 genes in the hippocampus of mice and rats. We also show that the induction of both genes occurs in the same cell and is impaired in cells depleted of C/EBP $\beta$. These data, together with a previous study from our laboratory showing a direct regulation of mouse $\mathrm{C} 3$ promoter by $C / E B P \beta$ in vitro [54], indicate that $C 3$ is a downstream target of $C / E B P \beta$ after a brain injury. Because C3 functions as a central complement component, most probably this gene plays an important role in the proinflammatory effects of $C / E B P \beta$ in the central nervous system.

The C/EBP $\beta$ gene plays an important role in neuroinflammation [61]. Its expression and the activity of the protein are upregulated by brain injury and inflammatory conditions and, additionally, C/EBP $\beta$ induces the expression of genes coding for proinflammatory cytokines $[16,62]$. The induction by KA of C/EBP $\beta$ expression in the hippocampus of mice and rats shown in this 


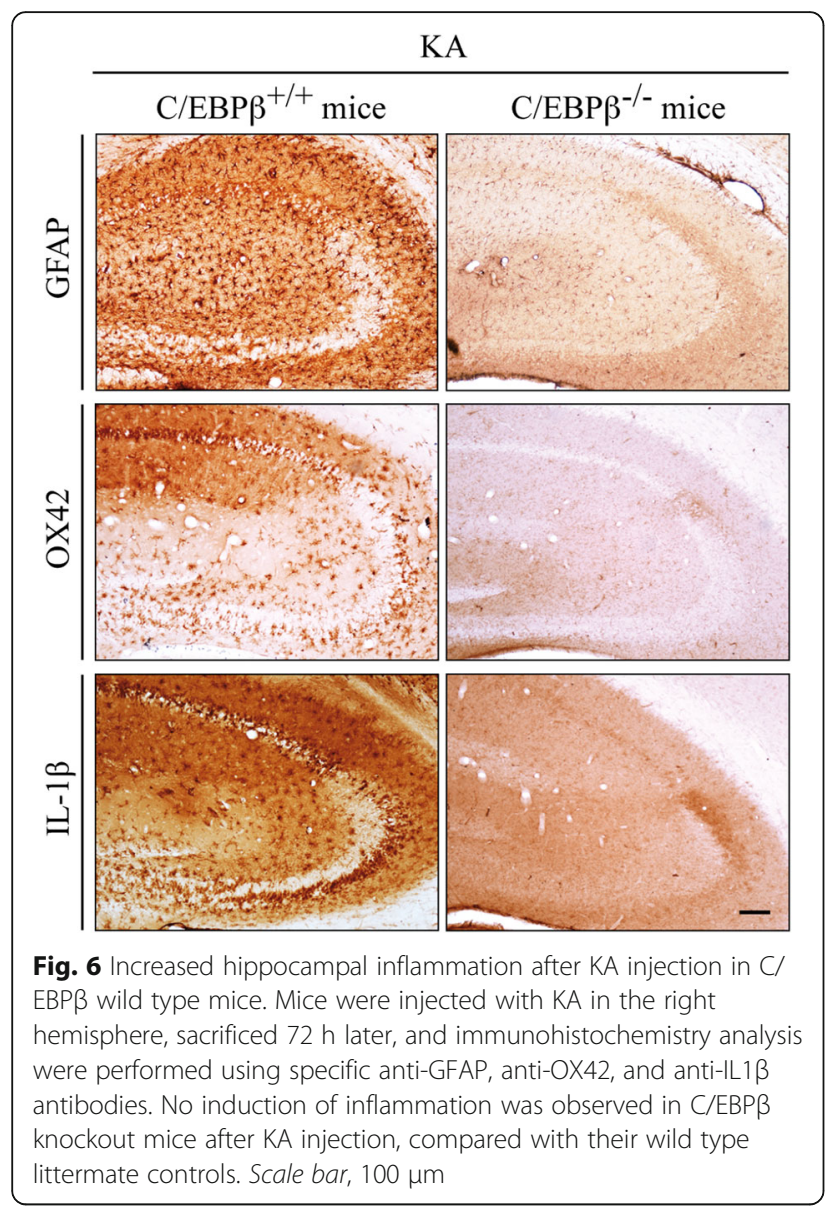

work is in agreement with previous data from our laboratory showing, in mice injected with $\mathrm{KA}$, an increase in the nuclear content of $\mathrm{C} / \mathrm{EBP} \beta$ mainly in the granular neurons of the dentate gyrus, but also in astrocytes and microglia cells [16]. Here we have extended these results by showing that $C / E B P \beta$ is also clearly induced in the CA1 and CA3 regions of the mouse hippocampus, which is in agreement with the described presence of $\mathrm{C} /$ EBP $\beta$ transcripts in these subfields of the adult mouse hippocampus, although at lower levels than in the dentate gyrus [63]. In contrast with the mouse, in the rat hippocampus the induction of $C / E B P \beta$ expression by KA was observed only in the CA3 subfield of the hippocampus, indicating a clear difference between both species. Interestingly, this enhancement in C/EBP $\beta$ protein levels occurs in neurons, as we previously observed in the dentate gyrus of mice. All these data are consistent with previous work showing the induction of $\mathrm{C} /$ EBP $\beta$ gene expression by $\mathrm{KA}$ and proinflammatory agents in primary cultured glial cells $[13,14,16]$.

$\mathrm{C} / \mathrm{EBP} \beta$ regulates the expression of various cytokine and chemokine genes, which play an important role in the regulation of innate and adaptive immunity [64-66]. The regulation of many of them is probably directly dependent of C/EBP $\beta$. Such is the case of the proinflammatory cytokines IL-1 $\beta$, IL6, and TNFalpha, where active C/EBP $\beta$ binding sites have been described in the corresponding promoters of the human genes $[67,68]$. The results presented in this work showing a parallel induction of $\mathrm{C} / \mathrm{EBP} \beta$ and $\mathrm{C} 3$ genes by $\mathrm{KA}$ and a lack of induction of $\mathrm{C} 3$ in $\mathrm{C} / \mathrm{EBP} \beta$ knockout mice, together with the commented previous results from our laboratory showing that $\mathrm{C} / \mathrm{EBP} \beta$ directly regulates the expression of C3 [54], clearly include $\mathrm{C} 3$ gene among those genes directly regulated by $\mathrm{C} / \mathrm{EBP} \beta$.

Accumulation of $\mathrm{C} 3$ protein after $\mathrm{KA}$ injection was observed in both glial and neuronal cells as shown by double labeling with a C3-specific antibody and cell type-specific markers. In the rat CA3 subfield, labeling with neurotrace, a specific neuronal marker, together with a C3 antibody, clearly indicates the presence of $\mathrm{C} 3$ protein inside the neurons and also in the surrounding area. Given the massive neuronal cell death that takes place in this region of the hippocampus, these observations suggest that $\mathrm{C} 3$ may be localized in those neurons that are already degenerating. In the case of glial cells, C3 accumulates in activated astrocytes and microglial cells. When double immunostaining for $\mathrm{C} 3$ and $\mathrm{C} / \mathrm{EBP} \beta$ was performed in the CA3 region of the mouse hippocampus after KA injection, both proteins were found in the same cells ( $C 3$ in the cytosol and C/EBP $\beta$ in the nucleus). These results further suggest that $\mathrm{C} 3$ expression could be regulated by $\mathrm{C} / \mathrm{EBP} \beta$ both in glial and neuronal cells and are consistent with other results showing that in the brain $\mathrm{C} 3$ can be produced by neuronal and glial cells [23, 69]. Specifically, in situ hybridization studies [32, 70-72] have shown that the C3 component is locally produced in glial cells and neurons and that the presence of $\mathrm{C} 3$ is not merely due to leakage of plasma proteins because of blood brain barrier damage.

Regarding the regulation of $\mathrm{C} 3$ gene expression by $\mathrm{C} /$ $\mathrm{EBP} \beta$, our results are in agreement with previous work showing that $C / E B P \beta$ plays an important role in the regulation of $\mathrm{C} 3$ expression by $\mathrm{IL}-1 \beta[73,74]$ and also with data from microarray analysis by our laboratory showing that the overexpression of $\mathrm{C} / \mathrm{EBP} \beta$ in neuroblastoma cells and its absence in the mouse hippocampus correlates, respectively, with an increase and a decrease in the amount of C3 transcripts [15, 54]. Moreover, the results presented here show that the increase in C3 mRNA after KA injection observed in control mice is not detected in $\mathrm{C} / \mathrm{EBP} \beta$-deficient mice, further suggesting that $\mathrm{C} / \mathrm{EBP} \beta$ is essential to induce $\mathrm{C} 3$ expression in the hippocampus after KA injection.

Consistent with the hypothesis that the $\mathrm{C} 3$ gene could play an important role as mediator of the 
proinflammatory effect of $\mathrm{C} / \mathrm{EBP} \beta$, some data in the literature implicate $\mathrm{C} 3$ as an active factor in neuronal damage in experimental models of inflammation [75, 76] and traumatic brain injury [77, 78]. In this regard, it has been shown that C3-deficient mice show less neuronal loss and microglial activation in several models of brain injury in different brain areas, including the hippocampus $[75,79-81]$. However, the function of the C3 is complex and a protective effect of $\mathrm{C} 3$ has been described in experimental models of Alzheimer's disease, probably as a consequence of favoring the clearance of $A \beta$ plaque [82, 83].

Excitotoxicity has been implicated as a pathogenic mechanism associated with different brain disorders, including acute brain injury and neurodegenerative diseases, including epilepsy [84, 85]. Glutamate is the major excitatory neurotransmitter in the central nervous system and a primary driver of the excitotoxic process. Although glutamate plays a central role in excitatory neurotransmission, alterations in glutamate homeostasis can have significant repercussions on neurons through the generation of neurotoxic and excitotoxic cascades. Particularly sensitive to KA injection are the hippocampal CA1 and CA3 regions, and the hilar neurons of the dentate gyrus [86]. Glial cells have an important role in the course of KA-induced hippocampal neurodegeneration. Activated astrocytes and microglial cells proliferate and increase the expression of genes involved in this degeneration process.

Regarding epilepsy, our results are in accordance with previous works showing an implication of the complement system in epilepsy. Specifically, an increase in C3 expression in the brain of patients with temporal lobe epilepsy $[87,88]$ has been shown, which is the common type in adults and is characterized by neuronal loss and gliosis in the hippocampus. The current literature demonstrates that injury to the brain results in a temporally orchestrated genetic response by neurons and glial cells, which involves signaling pathways that promote cell death and survival, yet a more complete elucidation of the exact molecular mechanisms is required. In particular, determination of the transcription factors involved and the downstream gene effectors they induce will provide invaluable insight into the neuroprotective signaling pathways. This will have immense public health implications, prevent ill health, and reduce the cost to society. In this regard, our results suggest that $\mathrm{C} / \mathrm{EBP} \beta$ and $\mathrm{C} 3$ might be important molecular new targets responsible for the neurodegeneration that occurs after a brain injury. It is important to note that this work shows that $C / E B P \beta$ regulates in vivo the expression of $\mathrm{C} 3$ in the hippocampus after an excitotoxic injury since C/EBP $\beta$ knockout mice do not show the induction of $\mathrm{C} 3$ after KA injection.

\section{Conclusions}

Collectively, our findings further demonstrate an activation of the $\mathrm{C} 3$ gene in vivo by $\mathrm{C} / \mathrm{EBP} \beta$ and suggest a role for $\mathrm{C} 3$ as a mediator of this transcription factor following a brain insult.

\section{Additional file}

Additional file 1: Double-immunofluorescence analysis showing C3 expression near microglia and blood vessels $72 \mathrm{~h}$ after KA injection in adult rats. All images represent the maximum intensity projection, and orthogonal views are also shown, generated by projecting $z$-series in the $x$ - and $y$-planes. Scale bar, 5 mm. (TIF 2327 kb)

\section{Abbreviations}

C/EBP $\beta$ : CCAAT/enhancer-binding protein $\beta$; C3: Complement component 3; KA: Kainic acid

\section{Acknowledgements}

We thank C.M. Croniger and R.H. Hanson (Case Western Reserve University, Cleveland, $\mathrm{OH}$ ) for providing the C/EBP $\beta$ knockout mice.

\section{Funding}

This work was supported by MINECO, Grant SAF2014-52940-R and partially financed with FEDER funds. CIBERNED is funded by the Instituto de Salud Carlos III. JAM-G was supported by CIBERNED. We acknowledge support of the publication fee by the CSIC Open Access Publication Support Initiative through its Unit of Information Resources for Research (URICI).

\section{Availability of data and materials}

The datasets supporting the conclusions of this article are included within the article and its additional file.

\section{Authors' contributions}

AP-C and AS conceived and designed the experiments. EH-E, DA-M, MS-S, EG, and JAM-G performed the experiments. DA-M, EH-E, AP-C, and AS analyzed the data. AP-C and AS wrote the manuscript. All authors read and approved the final manuscript.

\section{Competing interests}

The authors declare that they have no competing interests.

\section{Consent for publication}

Not applicable

\section{Ethics approval and consent to participate}

All procedures with animals were specifically approved by the "Ethics Committee for Animal Experimentation" of the Instituto de Investigaciones Biomédicas and carried out in accordance with the European Communities Council, directive 2010/63/EEC and National regulations, normative 53/2013.

\section{Author details}

${ }^{1}$ Instituto de Investigaciones Biomédicas, (CSIC-UAM), Arturo Duperier, 4, 28029 Madrid, Spain. ${ }^{2}$ Centro de Investigación Biomédica en Red sobre Enfermedades Neurodegenerativas (CIBERNED), 28031 Madrid, Spain. ${ }^{3}$ Departamento de Bioquímica y Biologia Molecular, Facultad de Medicina, UCM, 28040 Madrid, Spain. ${ }^{4}$ Departamento de Biología Celular, Facultad de Medicina, UCM, 28040 Madrid, Spain. ${ }^{5}$ Present Address: Departamento de Fisiología Médica y Biofísica, Instituto de Biomedicina de Sevilla, IBiS,

(Hospital Universitario Virgen del Rocío/CSIC/Universidad de Sevilla), 41013 Sevilla, Spain.

Received: 9 May 2016 Accepted: 4 October 2016

Published online: 21 October 2016

\section{References}

1. Ramji DP, Foka P. CCAAT/enhancer-binding proteins: structure, function and regulation. Biochem J. 2002;365:561-75. 
2. Tsukada J, Yoshida Y, Kominato Y, Auron PE. The CCAAT/enhancer (C/EBP) family of basic-leucine zipper (bZIP) transcription factors is a multifaceted highly-regulated system for gene regulation. Cytokine. 2011;54:6-19.

3. Calkhoven CF, Muller C, Leutz A. Translational control of C/EBPalpha and C/ EBPbeta isoform expression. Genes Dev. 2000;14:1920-32.

4. Wethmar K, Smink JJ, Leutz A. Upstream open reading frames: molecular switches in (patho)physiology. Bioessays. 2010;32:885-93.

5. Poli $\mathrm{V}$. The role of C/EBP isoforms in the control of inflammatory and native immunity functions. J Biol Chem. 1998;273:29279-82.

6. Croniger C, Leahy P, Reshef L, Hanson RW. C/EBP and the control of phosphoenolpyruvate carboxykinase gene transcription in the liver. J Biol Chem. 1998;273:31629-32.

7. Lekstrom-Himes J, Xanthopoulos KG. Biological role of the CCAAT/enhancerbinding protein family of transcription factors. J Biol Chem. 1998;273:28545-8.

8. Ramathal C, Bagchi IC, Bagchi MK. Lack of CCAAT enhancer binding protein beta (C/EBPbeta) in uterine epithelial cells impairs estrogen-induced DNA replication, induces DNA damage response pathways, and promotes apoptosis. Mol Cell Biol. 2010;30:1607-19.

9. Alberini CM, Ghirardi M, Metz R, Kandel ER. C/EBP is an immediate-early gene required for the consolidation of long-term facilitation in Aplysia. Cell. 1994;76:1099-114.

10. Taubenfeld SM, Milekic MH, Monti B, Alberini CM. The consolidation of new but not reactivated memory requires hippocampal C/EBPbeta. Nat Neurosci. 2001;:813-8

11. Menard C, Hein P, Paquin A, Savelson A, Yang XM, Lederfein D, BarnabeHeider F, Mir AA, Sterneck E, Peterson AC, et al. An essential role for a MEKC/EBP pathway during growth factor-regulated cortical neurogenesis. Neuron. 2002;36:597-610.

12. Cortes-Canteli M, Pignatelli M, Santos A, Perez-Castillo A. CCAAT/enhancerbinding protein beta plays a regulatory role in differentiation and apoptosis of neuroblastoma cells. J Biol Chem. 2002;277:5460-7.

13. Cardinaux JR, Allaman I, Magistretti PJ. Pro-inflammatory cytokines induce the transcription factors C/EBPbeta and C/EBPdelta in astrocytes. Glia. 2000;29:91-7.

14. Ejarque-Ortiz A, Medina MG, Tusell JM, Perez-Gonzalez AP, Serratosa J, Saura J. Upregulation of CCAAT/enhancer binding protein beta in activated astrocytes and microglia. Glia. 2007;55:178-88.

15. Cortes-Canteli M, Wagner M, Ansorge W, Perez-Castillo A. Microarray analysis supports a role for ccaat/enhancer-binding protein-beta in brain injury. J Biol Chem. 2004;279:14409-17.

16. Cortes-Canteli M, Luna-Medina R, Sanz-Sancristobal M, Alvarez-Barrientos A, Santos A, Perez-Castillo A. CCAAT/enhancer binding protein beta deficiency provides cerebral protection following excitotoxic injury. J Cell Sci. 2008:121:1224-34.

17. Cortes-Canteli M, Aguilar-Morante D, Sanz-Sancristobal M, Megias D, Santos A, Perez-Castillo A. Role of C/EBPbeta transcription factor in adult hippocampal neurogenesis. PLoS One. 2011;6:e24842.

18. Aguilar-Morante D, Cortes-Canteli M, Sanz-Sancristobal M, Santos A, Perez-Castillo A. Decreased CCAAT/enhancer binding protein beta expression inhibits the growth of glioblastoma cells. Neuroscience 2010. doi:10.1016/j.neuroscience.2010.12.025.

19. Aguilar-Morante D, Morales-Garcia JA, Santos A, Perez-Castillo A. CCAAT/ enhancer binding protein beta induces motility and invasion of glioblastoma cells through transcriptional regulation of the calcium binding protein S100A4. Oncotarget. 2015;6:4369-84.

20. Rininger A, Dejesus C, Totten A, Wayland A, Halterman MW. MKP-1 antagonizes C/EBPbeta activity and lowers the apoptotic threshold after ischemic injury. Cell Death Differ. 2012;19:1634-43.

21. Sandhir R, Berman NE. Age-dependent response of CCAAT/enhancer binding proteins following traumatic brain injury in mice. Neurochem Int. 2010;56:188-93.

22. Frank MM, Fries LF. The role of complement in inflammation and phagocytosis. Immunol Today. 1991;12:322-6.

23. Gasque P. Complement: a unique innate immune sensor for danger signals. Mol Immunol. 2004:41:1089-98

24. Flierl MA, Rittirsch D, Huber-Lang MS, Stahel PF. Complement in human disease. Clin Dev Immunol. 2013;2013:920474.

25. Holers VM. Complement and its receptors: new insights into human disease. Annu Rev Immunol. 2014;32:433-59.

26. Benoit ME, Tenner AJ. Complement protein C1q-mediated neuroprotection is correlated with regulation of neuronal gene and microRNA expression. J Neurosci. 2011;31:3459-69.
27. Fourgeaud L, Boulanger LM. Synapse remodeling, compliments of the complement system. Cell. 2007;131:1034-6.

28. Ricklin D, Hajishengallis G, Yang K, Lambris JD. Complement: a key system for immune surveillance and homeostasis. Nat Immunol. 2010;11:785-97.

29. Rutkowski MJ, Sughrue ME, Kane AJ, Ahn BJ, Fang S, Parsa AT. The complement cascade as a mediator of tissue growth and regeneration. Inflamm Res. 2010;59:897-905.

30. Stephan AH, Barres BA, Stevens B. The complement system: an unexpected role in synaptic pruning during development and disease. Annu Rev Neurosci. 2012;35:369-89.

31. Stevens B, Allen NJ, Vazquez LE, Howell GR, Christopherson KS, Nouri N, Micheva KD, Mehalow AK, Huberman AD, Stafford B, et al. The classical complement cascade mediates CNS synapse elimination. Cell. 2007;131:1164-78.

32. Veerhuis R, Nielsen HM, Tenner AJ. Complement in the brain. Mol Immunol. 2011:48:1592-603.

33. Perry VH, O'Connor V. C1q: the perfect complement for a synaptic feast? Nat Rev Neurosci. 2008;9:807-11.

34. Zabel MK, Kirsch WM. From development to dysfunction: microglia and the complement cascade in CNS homeostasis. Ageing Res Rev. 2013;12:749-56.

35. Stephan AH, Madison DV, Mateos JM, Fraser DA, Lovelett EA, Coutellier L, Kim L, Tsai HH, Huang EJ, Rowitch DH, et al. A dramatic increase of C19 protein in the CNS during normal aging. J Neurosci. 2013;33:13460-74.

36. Howell GR, Macalinao DG, Sousa GL, Walden M, Soto I, Kneeland SC, Barbay JM, King BL, Marchant JK, Hibbs M, et al. Molecular clustering identifies complement and endothelin induction as early events in a mouse model of glaucoma. J Clin Invest. 2011;121:1429-44.

37. Rosen AM, Stevens B. The role of the classical complement cascade in synapse loss during development and glaucoma. Adv Exp Med Biol. 2010;703:75-93.

38. Libbey JE, Kirkman NJ, Wilcox KS, White HS, Fujinami RS. Role for complement in the development of seizures following acute viral infection. J Virol. 2010;84:6452-60.

39. Moriyama M, Fukuhara T, Britschgi M, He Y, Narasimhan R, Villeda S, Molina H, Huber BT, Holers M, Wyss-Coray T. Complement receptor 2 is expressed in neural progenitor cells and regulates adult hippocampal neurogenesis. J Neurosci. 2011;31:3981-9.

40. Rahpeymai Y, Hietala MA, Wilhelmsson U, Fotheringham A, Davies I, Nilsson AK, Zwirner J, Wetsel RA, Gerard C, Pekny M, Pekna M. Complement: a novel factor in basal and ischemia-induced neurogenesis. EMBO J. 2006;25:1364-74.

41. Shinjyo N, Stahlberg A, Dragunow M, Pekny M, Pekna M. Complementderived anaphylatoxin C3a regulates in vitro differentiation and migration of neural progenitor cells. Stem Cells. 2009;27:2824-32.

42. Gasque P, Singhrao SK, Neal JW, Wang P, Sayah S, Fontaine M, Morgan BP. The receptor for complement anaphylatoxin C3a is expressed by myeloid cells and nonmyeloid cells in inflamed human central nervous system: analysis in multiple sclerosis and bacterial meningitis. J Immunol. 1998:160:3543-54

43. McGeer PL, McGeer EG. Inflammation and neurodegeneration in Parkinson's disease. Parkinsonism Relat Disord. 2004:10 Suppl 1:S3-7.

44. Aiyaz M, Lupton MK, Proitsi P, Powell JF, Lovestone S. Complement activation as a biomarker for Alzheimer's disease. Immunobiology. 2012;217:204-15.

45. Cervera A, Planas AM, Justicia C, Urra X, Jensenius JC, Torres F, Lozano F, Chamorro A. Genetically-defined deficiency of mannose-binding lectin is associated with protection after experimental stroke in mice and outcome in human stroke. PLoS One. 2010:5:e8433.

46. Lopez ME, Klein AD, Scott MP. Complement is dispensable for neurodegeneration in Niemann-Pick disease type C. J Neuroinflammation. 2012;9:216.

47. Prineas JW, Parratt JD. Oligodendrocytes and the early multiple sclerosis lesion. Ann Neurol. 2012;72:18-31.

48. Proitsi P, Lupton MK, Dudbridge F, Tsolaki M, Hamilton G, Danilidou M, Pritchard M, Lord K, Martin BM, Johnson J, et al. Alzheimer's disease and age-related macular degeneration have different genetic models for complement gene variation. Neurobiol Aging. 1843;2012(33):1843.e9-17.

49. Wang Y, Hancock AM, Bradner J, Chung KA, Quinn JF, Peskind ER, Galasko D, Jankovic J, Zabetian CP, Kim HM, et al. Complement 3 and factor $h$ in human cerebrospinal fluid in Parkinson's disease, Alzheimer's disease, and multiplesystem atrophy. Am J Pathol. 2011;178:1509-16.

50. Michailidou I, Willems JG, Kooi EJ, van Eden C, Gold SM, Geurts JJ, Baas F, Huitinga I, Ramaglia V. Complement C1q-C3-associated synaptic changes in multiple sclerosis hippocampus. Ann Neurol. 2015;77:1007-26. 
51. Zanjani H, Finch CE, Kemper C, Atkinson J, McKeel D, Morris JC, Price JL. Complement activation in very early Alzheimer disease. Alzheimer Dis Assoc Disord. 2005;19:55-66.

52. Lian $\mathrm{H}$, Litvinchuk $\mathrm{A}$, Chiang AC, Aithmitti $\mathrm{N}$, Jankowsky JL, Zheng $\mathrm{H}$. Astrocyte-microglia cross talk through complement activation modulates amyloid pathology in mouse models of Alzheimer's disease. J Neurosci. 2016:36:577-89.

53. Lian H, Yang L, Cole A, Sun L, Chiang AC, Fowler SW, Shim DJ, RodriguezRivera J, Taglialatela G, Jankowsky JL, et al. NFkappaB-activated astroglial release of complement C3 compromises neuronal morphology and function associated with Alzheimer's disease. Neuron. 2015;85:101-15.

54. Hernandez-Encinas E, Aguilar-Morante D, Cortes-Canteli M, MoralesGarcia JA, Gine E, Santos A, Perez-Castillo A. CCAAT/enhancer binding protein beta directly regulates the expression of the complement component 3 gene in neural cells: implications for the proinflammatory effects of this transcription factor. J Neuroinflammation. 2015;12:14.

55. Screpanti I, Romani L, Musiani P, Modesti A, Fattori E, Lazzaro D, Sellitto C, Scarpa S, Bellavia D, Lattanzio G, et al. Lymphoproliferative disorder and imbalanced T-helper response in C/EBP beta-deficient mice. EMBO J. 1995;14:1932-41.

56. Asua T, Bilbao A, Gorriti MA, Lopez-Moreno JA, Del Mar AM, Navarro M, Rodriguez de Fonseca F, Perez-Castillo A, Santos A. Implication of the endocannabinoid system in the locomotor hyperactivity associated with congenital hypothyroidism. Endocrinology. 2008;149:2657-66.

57. Livak KJ, Schmittgen TD. Analysis of relative gene expression data using real-time quantitative $P C R$ and the 2(-delta delta $C(T))$ Method. Methods. 2001:25:402-8

58. Morales-Garcia JA, Redondo M, Alonso-Gil S, Gil C, Perez C, Martinez A, Santos A, Perez-Castillo A. Phosphodiesterase 7 inhibition preserves dopaminergic neurons in cellular and rodent models of Parkinson disease. PLoS One. 2011;6:e17240

59. Morales-Garcia JAE-AV, Alonso-Gil S, Sanz-SanCristobal M, Lopez-Moreno JA, Gil C, Martinez A, Santos A, Perez-Castillo A. Phosphodiesterase7 inhibition activates adult neurogenesis in hippocampus and subventricular zone in vitro and in vivo. Stem Cells. 2016. doi:10.1002/stem.2480.

60. Schmued LC, Albertson C, Slikker Jr W. Fluoro-Jade: a novel fluorochrome for the sensitive and reliable histochemical localization of neuronal degeneration. Brain Res. 1997;751:37-46.

61. Pulido-Salgado M, Vidal-Taboada JM, Saura J. C/EBPbeta and C/EBPdelta transcription factors: basic biology and roles in the CNS. Prog Neurobiol. 2015;132:1-33.

62. Kapadia R, Tureyen K, Bowen KK, Kalluri H, Johnson PF, Vemuganti R. Decreased brain damage and curtailed inflammation in transcription factor CCAAT/enhancer binding protein beta knockout mice following transient focal cerebral ischemia. J Neurochem. 2006;98:1718-31.

63. Nadeau S, Hein P, Fernandes KJ, Peterson AC, Miller FD. A transcriptional role for C/EBP beta in the neuronal response to axonal injury. Mol Cell Neurosci. 2005;29:525-35.

64. Mayer TZ, Simard FA, Cloutier A, Vardhan H, Dubois CM, McDonald PP. The p38-MSK1 signaling cascade influences cytokine production through CREB and C/EBP factors in human neutrophils. J Immunol. 2013;191:4299-307.

65. Serrat N, Sebastian C, Pereira-Lopes S, Valverde-Estrella L, Lloberas J, Celada A. The response of secondary genes to lipopolysaccharides in macrophages depends on histone deacetylase and phosphorylation of C/EBPbeta. J Immunol. 2014;192:418-26.

66. Zhang Z, Bryan JL, DeLassus E, Chang LW, Liao W, Sandell L. CCAAT/ enhancer-binding protein beta and NF-kappaB mediate high level expression of chemokine genes CCL3 and CCL4 by human chondrocytes in response to IL-1beta. J Biol Chem. 2010;285:33092-103.

67. Pope RM, Leutz A, Ness SA. C/EBP beta regulation of the tumor necrosis factor alpha gene. J Clin Invest. 1994;94:1449-55.

68. Tsukada J, Saito K, Waterman WR, Webb AC, Auron PE. Transcription factors NF-IL6 and CREB recognize a common essential site in the human prointerleukin 1 beta gene. Mol Cell Biol. 1994;14:7285-97.

69. D'Ambrosio AL, Pinsky DJ, Connolly ES. The role of the complement cascade in ischemia/reperfusion injury: implications for neuroprotection. Mol Med. 2001;7:367-82.

70. Fischer B, Schmoll H, Riederer P, Bauer J, Platt D, Popa-Wagner A. Complement C1q and C3 mRNA expression in the frontal cortex of Alzheimer's patients. J Mol Med (Berl). 1995;73:465-71.
71. Thomas A, Gasque P, Vaudry D, Gonzalez B, Fontaine M. Expression of a complete and functional complement system by human neuronal cells in vitro. Int Immunol. 2000;12:1015-23.

72. Yu JX, Bradt BM, Cooper NR. Constitutive expression of proinflammatory complement components by subsets of neurons in the central nervous system. J Neuroimmunol. 2002;123:91-101.

73. Maranto J, Rappaport J, Datta PK. Role of C/EBP-beta, p38 MAPK, and MKK6 in IL-1 beta-mediated C3 gene regulation in astrocytes. J Cell Biochem. 2011;112:1168-75

74. Wilson DR, Juan TS, Wilde MD, Fey GH, Darlington GJ. A 58-base-pair region of the human C3 gene confers synergistic inducibility by interleukin-1 and interleukin-6. Mol Cell Biol. 1990;10:6181-91.

75. Bodea LG, Wang Y, Linnartz-Gerlach B, Kopatz J, Sinkkonen L, Musgrove R, Kaoma T, Muller A, Vallar L, Di Monte DA, et al. Neurodegeneration by activation of the microglial complement-phagosome pathway. J Neurosci. 2014;34:8546-56.

76. Ramaglia V, Hughes TR, Donev RM, Ruseva MM, Wu X, Huitinga I, Baas F, Neal JW, Morgan BP. C3-dependent mechanism of microglial priming relevant to multiple sclerosis. Proc Natl Acad Sci U S A. 2012;109:965-70.

77. Bellander BM, Lidman O, Ohlsson M, Meijer B, Piehl F, Svensson M. Genetic regulation of microglia activation, complement expression, and neurodegeneration in a rat model of traumatic brain injury. Exp Brain Res. 2010;205:103-14.

78. Leinhase I, Schmidt OI, Thurman JM, Hossini AM, Rozanski M, Taha ME, Scheffler A, John T, Smith WR, Holers VM, Stahel PF. Pharmacological complement inhibition at the C3 convertase level promotes neuronal survival, neuroprotective intracerebral gene expression, and neurological outcome after traumatic brain injury. Exp Neurol. 2006;199:454-64.

79. Perez-Alcazar M, Daborg J, Stokowska A, Wasling P, Bjorefeldt A, Kalm M, Zetterberg H, Carlstrom KE, Blomgren K, Ekdahl CT, et al. Altered cognitive performance and synaptic function in the hippocampus of mice lacking C3. Exp Neurol. 2014;253:154-64.

80. Shi Q, Colodner KJ, Matousek SB, Merry K, Hong S, Kenison JE, Frost JL, Le KX, Li S, Dodart JC, et al. Complement C3-deficient mice fail to display age-related hippocampal decline. J Neurosci. 2015;35:13029-42.

81. Yang S, Nakamura T, Hua Y, Keep RF, Younger JG, He Y, Hoff JT, Xi G. The role of complement C3 in intracerebral hemorrhage-induced brain injury. J Cereb Blood Flow Metab. 2006;26:1490-5.

82. Maier M, Peng Y, Jiang L, Seabrook TJ, Carroll MC, Lemere CA. Complement C3 deficiency leads to accelerated amyloid beta plaque deposition and neurodegeneration and modulation of the microglia/macrophage phenotype in amyloid precursor protein transgenic mice. J Neurosci. 2008;28:6333-41.

83. Wyss-Coray T, Yan F, Lin AH, Lambris JD, Alexander JJ, Quigg RJ, Masliah E. Prominent neurodegeneration and increased plaque formation in complement-inhibited Alzheimer's mice. Proc Natl Acad Sci U S A. 2002;99:10837-42

84. Parsons MP, Raymond LA. Extrasynaptic NMDA receptor involvement in central nervous system disorders. Neuron. 2014;82:279-93.

85. Williams CJ, Dexter DT. Neuroprotective and symptomatic effects of targeting group III mGlu receptors in neurodegenerative disease. Neurochem. 2014;129:4-20.

86. Sperk G. Kainic acid seizures in the rat. Prog Neurobiol. 1994;42:1-32.

87. Aronica E, Boer K, van Vliet EA, Redeker S, Baayen JC, Spliet WG, van Rijen PC, Troost D, da Silva FH, Wadman WJ, Gorter JA. Complement activation in experimental and human temporal lobe epilepsy. Neurobiol Dis. 2007;26:497-511.

88. Jamali S, Bartolomei F, Robaglia-Schlupp A, Massacrier A, Peragut JC, Regis J, Dufour H, Ravid R, Roll P, Pereira S, et al. Large-scale expression study of human mesial temporal lobe epilepsy: evidence for dysregulation of the neurotransmission and complement systems in the entorhinal cortex. Brain. 2006;129:625-41. 